\title{
Analysis of Increasing the Savings of the Poor Through the Community Empowerment Program
}

\author{
Meiske MN Sihombing ${ }^{1 *}$ Firmansyah $^{2}$ FX. Sugiyanto ${ }^{3}$ \\ ${ }^{1,2,3}$ University of Diponegoro \\ *Corresponding author.Email: meiskemurni@gmail.com
}

\begin{abstract}
One of the requirements for business is funding. On the other hand, this is often not owned especially by groups of poor. The government have been made such policy to overcome the poverty. One of the efforts is revolving loans of the National Program for Urban Community Empowerment (PNPM Mandiri Perkotaan). By the loan, it is anticipated that there is an addition to their savings, and at the end the poor can increase their welfare. The program has been implementing in Hedam Village of Jayapura City since 2010. This research was to know whether the loan can improve welfare through saving. The Ordinary Least Square (OLS) is used to analyze data from 67 respondents. Based on the results, the loans have a positive effect on savings. On the other side, 64.6 percent of savings can be explained by income and loans. By this program, they can create a new job because most of recipients stated that these businesses as their main job. It is like a favor because most of households must support 2-3 members of their family and were majority perform by women recipients. In addition, the education level of the poor mostly primary and secondary school. Therefore, by the committed assistance of PNPM Mandiri facilitators, such loans can influence the savings of the poor. It may be the good sign for reducing the poverty. Although there are other variables may influence the model which have not been taken into this study.
\end{abstract}

Keywords: saving, poverty, loan, community

\section{INTRODUCTION}

Many factors can cause poverty. It is very difficult to determine which factors are the real cause. Starting from output growth or productivity, net wage rate, income distribution, employment, investment rate, inflation, taxes, transfers, allocation and quality of resources, technology, education level, physical condition of the region, work ethic, cultural, natural disasters until the war $[1,2,3]$. Low of productivity levels cause low of income which influence the saving. This also has an influence on capital formation. Such conditions lead to a shortage of capital goods. For poor countries, both of low investment and low income cause the limited market area. Thus, poverty will continue. According to reference [4] the circumstances which create barriers to capital formation can lead to poverty. Thus, the developing countries which their low savings rates and investment incentives make that impossible to establish high levels of capital.

The poverty alleviation policies in regional autonomy era make it possible to reduce poverty as spatial and temporal distances, it become closer to the poor. However, the limited coverage of formal Microfinance
Institutions can be an obstacle for the poor. In Papua, especially in the main districts, it has few microfinance institutions compared to its size. 6 BPR, 5 Baitul Maal Wan Tanwil Yinbuk, 30 BRI Units, 501 cooperatives, 13 Credit Unions, 5 Perum Pegadaian and 24 Savings and Loans $[5,6]$. The high cost of reaching the remote areas is one of the reasons for the formal institutions to reach those. One strategy to subdue this limited access is by community development approach. One of them is the National Program for Urban Community Empowerment (Urban PNPM Mandiri). The aim of this program is to empower the community through three main activities namely infrastructure, social and economy (Tridaya). In economy activity, there is revolving loan. This loan is micro loan to poor community in villages area who has self-supporting group.

In revolving loans, it is expected that the poor who have trouble in accessing formal financial services, shall earn it. Poor households can improve their economic conditions and provide lessons in loan management with such capital. This loan is focused on poorly identified communities wich at least 30 percent of the borrowers are women. The amount and interest rate of loan that appeals 
to the poor and applies the group's mutual responsibility system [7].

The Province of Papua is one of the provinces in Indonesia, whose percentage of the poor was 31.52 percent by 2014. It was higher than the average of Indonesia's poor which was 10.96 percent [8]. Jayapura city with the percentage of poor population was 16.19 percent, the city has been implementing Urban Community Empowerment since 2008. The research location is Hedam Village in Heram District, Jayapura City. The village is close to the center of government and economy. 62.45 percent of the 13,868 people were high school and junior high school level [9]. The livelihood of the population was dominated by traders, transportation services and home industries.

Thus, the purpose of the research is to discover the effect of revolving loan program on poverty alleviation in urban areas. Are loan and business income able to increase the savings of the poor?

\section{LITERATURE REVIEW}

Central Bureau of Statistics defines poverty with the standard of food and nonfood poverty line. Standard of food is the value of consumption expenditure of food equivalent to 2100 calories per capita per day. Standard of nonfood is the number of rupiahs to meet minimum nonfood needs such as housing, health, education, transportation, clothing and other goods/services. While the National Population and Family Planning Agency uses household units to measure poverty which is characterized by the difficulty of fulfilling economy and non-economy needs.

Inequality of resources ownership is a root of poverty [10]. In addition, differences in access and capital as well as differences in the quality of human resources could influence productivity and wages. For poor countries, low investment together with low-income levels cause the limited market area. Reference Nurkse [4] told that the circumstances which create barriers to the creation of capital formation could cause poverty. In developing countries, the low of saving rates and investment incentives make it impossible to establish high levels of capital. In line with the result of Social Monitoring and Early Response Unit Research Institute [11], the causes of poverty were the failure of ownership especially land and capital, low productivity and the level of capital formation in the community.

The diversity of problems lead to poverty alleviation policies needs to be addressed from the root of the problem. Reference Robinson [12] said that the poor are classified into 3 groups: a) the extreme poor, those who are unpaid and unproductive; b) the economically active working poor, the poor but have economic activity; c) the lower income, those who have a few of income. The approach for each group will vary. The first group needs direct approaches to food programs, transfers and job creation. For other groups using an indirect approach such as micro loan development, creating a conducive climate for SMEs and synergies with large companies. Yet, the weaknesses during poverty alleviation in the past were the programs still centralistic, macro, less transformative, unsustainable and viewed the society as an object.

According to reference Uddin et al. [13] that examine various rural development programs to reduce the poor in Bangladesh. The study uses quantitative approach with survey. The study utilizes various dimensions of poor such as income and social empowerment. And the result indicates that rural development programs such as housing, agriculture, health and education increasing income and social empowerment. This result supported by another research [14]. The multidimensional poverty was decline among the member of Azad Jammu and Kashmir Community Development Program. It consists several aspects such as living standard, health and education. They found that development programs at community level able to actualize the programs more effectively.

However, not all studies show the same results. China's poverty alleviation program that finances public investment in poor villages evidently did not increase the poor's incomes and consumptions. The interesting finding from this study is the government has an important role for the distribution of program benefits. The program may increase the monitoring and accountability [15]. Their results reveal that decentralization and community-based development are not magic bullets for poor alleviation.

Among many programs of poverty alleviation, one of the efforts of poverty alleviation is by empowering the community. This approach is empowering the community to recognize the problems in developing and helping themselves and their group to be better condition. One of them is the National Program for Urban Community Empowerment (PNPM Mandiri Perkotaan) which was originally called the Urban Poverty Program.

The Urban Poverty Program has three main activities namely infrastructure, social and economy (Tridaya). There is a loan in the economy, which is micro-loans to the poor in certain urban villages. Sources of funds come from direct public funds, government expenditures (Anggaran Pendapatan dan Belanja Daerah/APBD), the private sector, NGO's and other sources. Each loan contains a risk of nonrepayment, which covers by a reserve of loan. This reserve is formed every month according to the quality of the group of borrowers. According to Bank Indonesia's regulation $13 / 26 / \mathrm{PBI} / 2011$, the risk reserve for collectability is at least 0.5 percent of the loan balance for good borrowers, 
at least 10 percent for less smooth, 50 percent for the doubtful group and 100 percent for the bad.

The loan decision is based on the analysis of character, condition, capacity, capital and collateral of borrowers. The allowed collateral in the National Program for Urban Community Empowerment is in the form of joint liability only. The groups must deposit savings, principal installments and loan services. The next loan is served if the borrowers have savings. The facilitation and monitoring process are undertaken by facilitators, experts and the community. According to reference [16], to detect the impact of loans consist of 3 levels with such variables: household level (increase in household income, income diversification), business level (increase of business income, fixed assets, labor) and individual level (increase of savings individual, future planning and self-esteem).

\section{METHODS}

The research was conducted in Hedam Village of Heram District in Jayapura City. Data were collected by questionnaires on 67 respondents from 205 population. These respondents come from 44 community self-help groups in 2012-2014.

Economy activities of participants in this study consists of three business groups namely a) trade business such as grocery, food, staples and miscellaneous business; b) services business such as transportation, tailor, cafes, party equipment rental, key experts and photocopy; c) industries business such as food and crafts.

Those 67 respondents were selected by Stratified Random Sampling which are a) trade, 35 households; b) service, 22 households; c) industry, 10 households.

The results analyzed by Ordinary Least Square method on model below:

$Y_{i}=\beta_{0}+\beta_{1} X_{i}+\beta_{2} Z_{i}+\varepsilon_{i}$

$Y_{i}$ is saving of respondent $-\mathrm{i} ; X_{i}$ is loan of respondent $-\mathrm{i} ; Z_{i}$ is business income of respondent $-\mathrm{i}$.

The definition of variables used in the study are a) Revolving loan, used for extensifying activities as well as the intensification of productive enterprises, which are owned by household as members of community self-help groups; b) Business income, revenues earned from business results. Retrieved from total sales for a month minus total cost for a month; c) Saving, the amount of deposits that are routinely performed by the participants and counted for a month.

\section{RESULTS AND DISCUSSION}

The effect of loan program on poverty alleviation in urban areas will be shown in regression analysis below.
However, it is important to know the description of recipients who effected by this program.

\subsection{Description Analysis of Respondents}

The description of recipients shows in two categories, the description of recipients and the description of businesses. In the first category, the description of recipients describes the general condition of recipients such as age, education level, gender and family dependent. And the second category describes the condition of their businesses like the kind of business, capital, workers, income and their saving.

In general, the description of recipients shows that most of the businesses are carried out by productive age. It shows by 46.27 percent recipients between $40-49$ years old and between 50-59 years old ( 35.82 percent). Also, 65.67 percent of them are recipients with family dependents of 2-3 people. On the other hand, the education level is dominated by primary school graduates (43.28 percent), especially on trading businesses. The other are junior high school graduates (40.30 percent), high school graduates (11.94 percent) and college graduates (4.47 percent). Besides that, 58.21 percent of recipients are females especially in-service businesses and home industries. While the trade is mostly run by men (60 percent).

With the condition of such recipients, the program is able to create new jobs. It shown by the description of business which most of recipients stated that the business is run as main job (88.06 percent). And most of the jobs are trading businesses ( 52.24 percent) and services (32.84 percent). The other is home industries (14.92 percent).

The businesses mostly classified as small businesses They have capital range from IDR 300,000 up to IDR 900,000 (37.31 percent) and from IDR 1,000,000 up to IDR 2,000,000 (34.33 percent). The rest is above IDR $2,000,000$. Also, they dominated by business with one worker (50.75 percent) and 2-3 workers (44.78 percent). Moreover, the business income is at least IDR $300,000 /$ month up to above IDR $800,000 /$ month. After following this program, they able to save IDR 20,000 up to IDR 100,000 .

According to those descriptions that the implementation of loan in Hedam Village is focus on small business especially trade, with more female recipients. The education level of the respondents was quite low. It could be a barrier in the management of loans. However, in the Urban Poverty Program, there is a support conducted by facilitators, especially in managing loans to have savings.

\subsection{Regression Analysis}

According to Table 1, the result shows that the loan and income significantly have a positive influence on saving (at $\alpha=0.05$ ). This indicates that an increase of 
loan can increase the savings. And an increase of income, the saving will increase. Yet, there are other variables may determine the saving because just 64.6 percent saving can be explained by loan and business income.

Table 1. The Result of Regression Analysis

\begin{tabular}{|c|c|c|c|c|}
\hline \multirow[b]{2}{*}{ Variable } & \multicolumn{4}{|c|}{ Estimation of Ordinary Least Square ${ }^{a}$} \\
\hline & Coefficient & Std. Error & $t$-Stat & Prob. \\
\hline C & 22.80667 & 2.9208 & 7.8083 & 0.00 \\
\hline$x$ & $1.65 E-06$ & 7.32E-07 & 2.2487 & 0.03 \\
\hline Z & 3.18E-05 & $3.88 \mathrm{E}-06$ & 8.1916 & 0.00 \\
\hline
\end{tabular}

\section{CONCLUSION}

The loan in Hedam Village provided to poor households that have small businesses. And the majority of the recipients are women. Beside that most of households must supports 2-3 member of their family. In addition, the education level of the poor mostly primary and secondary school. Therefore, by the committed assistance of the National Program for Urban Community Empowerment facilitators, such loans can influence the savings of the poor. It may be the good sign for reducing the poverty. However, the effect is very small on loans. It could be due to the small number of respondents. Besides that, in light of complexity of poverty roots, there are other variables have not been included in this study.

\section{REFERENCES}

[1] T.T.H. Tambunan, The economy of Indonesia: Theory and empirical analysis, Bogor, Ghalia Indonesia, 2011.

[2] M.T. Majeed and M.N. Malik, Determinants of household poverty: empirical evidence from Pakistan, The Pakistan Development Review, vol. 54 (4), 2014, pp. 701-717.

[3] M. Cao, D. Xu, F. Xie, E. Liu, S. Liu, The influence factors analysis of households' poverty vulnerability in southwest ethnic areas of China based on the hierarchical linear model: a case study of Liangshan
Yi autonomous prefecture, Applied Geography, vol 66, 2016, pp. 144-152.

[4] R. Nurkse, Problems of Capital Formation in Underdeveloped Countries, Oxford: Basis Blackwell, 1953, pp. 163.

[5] E.A. Landiyanto, Alternative strategy to reduce proverty in Papua through microfinance development, Munich Personal RePEc Archive, no. 4391, 2007.

[6] Bank Indonesia, Indonesian Banking Statistic, vol. 13, Jakarta: 2014.

[7] Departement of Public Works Directorate General of Human Settlements, Technical Guidelines for Revolving Loan Activities: The National Program for Urban Community Empowermen, Jakarta: 2008.

[8] Central Bureau of Statistics, Papua Province in Figures, Jayapura: 2015.

[9] Hedam Village Office, Monograph of Hedam Village, Jayapura: 2014.

[10] M. Kuncoro, Development Economy: Theory, Problem and Policy, Yogyakarta: AMP YKPN, 2000.

[11] Social Monitoring and Early Response Unit Research Institute, The Basic Information of Poverty Avelliation, Jakarta, 2001.

[12] M.S. Robinson, Microfinance Revolution: Lessons from Indonesia, The World Bank, 2001.

[13] M.M. Uddin, M.M. Chowdhury, A. Ahmad, The impact of rural development program on poverty alleviation: a case of bangladesh, Global Journal of Management and Business Research: Administration and Management, vol. 15 (4), 2015 , pp. 17-24.

[14] G. Hameed, A. Saboor, A.U. Khan, I. Ali, M.K. Wazir, Impact of community development in poverty reduction: reflections of azad jammu and kashmir community development program, Social Indicators Research, vol. 130 (3), 2017, pp. 10731086.

[15] A. Park and S. Wang, Community-based development and poverty alleviation: an evaluation of China's poor village investment program, Journal of Public Economics: Elsevier, vol. 94, 2010, pp. 790-799.

[16] P. Boediono, The Impact of Fund Loan, Akatiga and Yayasan Peramu, 2005. 